\title{
ENVIRONMENTAL PERCEPTION AND ACTIVITIES IN ENVIRONMENTAL EDUCATION BASED ON SOCIO-ECOLOGICAL RESILIENCE
}

\author{
Mirlaine Rotoly de Freitas ${ }^{1}$, Stella V. B. G. Matias, Renato L. G. Macedo ${ }^{2}$, \\ Nelson Venturin ${ }^{3}$, Matheus Puggina de Freitas ${ }^{4}$
}

\begin{abstract}
The concept of environment in students from primary levels and high school was achieved from an environmental perception analysis based on drawings, while the most important proenvironmental actions, according to the students' opinion, were captured using a survey. The data from environmental perception and the level of pro-environmental actions were correlated to each other using principal component analysis. The hypothesis that meaningful proenvironmental actions are related to the level of environmental perception was confirmed. Thus, teaching-learning activities in environmental education focused on socio-ecological resilience were proposed to improve the environmental perception of students and, ultimately, to lead effective pro-environmental actions.
\end{abstract}

Keywords: environmental perception; pro-environmental actions; educational methodology; socio-ecological system; resilience thinking

\section{RESUMO}

A concepção de ambiente para estudantes da educação básica e ensino médio foi obtida a partir da análise da percepção ambiental baseada em desenhos, enquanto as ações pró-ambientais mais importantes apontadas pelos estudantes foram capturadas por meio de um survey. Os dados de percepção ambiental e o nível das ações pró-ambientais foram correlacionados usando análise por componentes principais. A hipótese de que ações pró-ambientais significativas estão relacionadas com o nível de percepção ambiental foi confirmada. Portanto, atividades de ensino em educação ambiental baseada em resiliência sócio-ecológica são propostas para melhorar a percepção ambiental de estudantes e, consequentemente, conduzir a ações pró-ambientais efetivas.

Palavras-chave: percepção ambiental; ações pró-ambientais; metodologia educacional; sistema sócio-ecológico; resiliência

\section{INTRODUCTION}

There is a lack of educational methodologies to make the environmental learning process more effective. Meaningful environmental learning happens when somebody has the competence to transfer the acquired knowledge to daily situations. Thus, the role of an educator in the teaching-learning process is a fundamental task, by recovering the

1 Bacharel e licenciada em Geografia pela UNESP - Rio Claro. Mestre em Ciências Florestais pela UFLA. Doutoranda em Ciências Florestais (Manejo Ambiental) pela UFLA.

2 Universidade Federal de Lavras.

3 Universidade Federal de Lavras.

4 Universidade Federal de Lavras. 


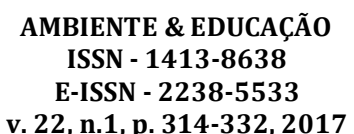

previous knowledge of students and organizing the construction of knowledge (AUSUBEL, 1963; WOOLFOLK et al., 2010).

The key discussions in the United Nations environmental meetings, especially in the United Nations Conference on Sustainable Development (Rio+20), have been focused on sustainability of environmental resources and the formation of resilient citizens. A resilient person considers social and ecological systems as linked and nested and integrates social and ecological values in managing the environment for change and sustainability (KRASNY et al., 2010; FAZEY, 2010).

In formal environmental education, people should be educated in order to have technical and complex knowledge about environmental problems and to rationalise sustainably. Environmental complexity, in this context, refers to the connection among the maximum number of possible elements, phenomena and processes. Individuals can express their conception of the environment through the level of interconnection among natural elements, anthropogenic components and human actions (KRASNY, 2009; KRASNY et al., 2010). The environmental complexity and socio-ecological system define the elements of the environment and their interrelationships. The resilience concept is related to the way in which these elements interact in favor of environmental conservation and, therefore, it is strongly related to the concept of sustainability. Bearing this in mind, a main topic of the United Nations Conference on Sustainable Development was entitled "Resilient people, resilient planet: A future worth choosing".

The formation of complex conceptions on the environment and resilience of the socio-ecological system should be strengthened during the scholar's development. The conservationist conception and, consequently, conservationist environmental actions should be consolidated in the long term. On the other hand, short term practices are also required, because of the necessity to preserve the environment; research on this this aspect deals with "optimization for conservation" (MARGULES et al., 2000; ROUGHGARDEN AND SMITH, 1996; LANDE et al., 1994), which includes practices such as public inspection and intervention. Ideally, socio-ecological resilience and optimization for conservation practices must be merged to solve questions requiring urgent solutions, but also prepare the current and future generations to preserve the environment (FISCHER et al., 2009).

Environmental perception can be used to map the level of environmental complexity of students (FREITAS et al., 2010). In this work, the environmental 
perception was captured using environment drawings strategy, deemed to be a reliable and efficient method for obtaining the environmental conception from any scholar age and even for non-students. For instance, a type of landscape perception using photoelicitation has been used by Sherren and coworkers (2012) to study the agricultural adaptation of Australian farmers; from this approach, the landscape perceptions of holistic management graziers were compared with those of more conventional graziers. Recently, children drawings obtained from urban and rural groups was used to interpret students' learning and preferences in Environmental Education (LABINTAH, SHINOZAKI, 2014); this study suggested a significant positive relationship between the children's level of environmental learning among urban children and their preferences in particular towards outdoor physical and cognitive interpretations within an active environment. However, a didactic strategy to strengthen and balance the knowledge, in an integrative way, is expected to complement the interactive approach. Such a strategy is proposed in this study by means of lesson plans.

Data analysis was performed using multivariate statistics and, based on the outcomes of the principal component analysis (relating environmental perception with the level of pro-environmental actions, categorized into 'sensibility', 'comprehension', 'responsibility' and 'competence and citizenship' levels), teaching activities were proposed. The proposed methodology merges the theories of environmental complexity, socio-ecological system and resilience thinking to promote an effective environmental learning. It is worth mentioning that multivariate analysis is required in this scope because of the numerous samples (students) evaluated according to a diverse set of variables, namely the scores in environmental perception and the categories of proenvironmental actions. These data are crossed in order to find a tendency to be used in the prediction of pro-environmental actions and, therefore, to elaborate strategies to improve them. Accordingly, these strategies should be focused on an environmental education inspired by resilience thinking and socio-ecological system.

\section{METHODOLOGY}

The proposed methodology has been recently reported by us (FREITAS et al., 2016) and is now applied according to the procedure further detailed. The method used to analyse the environmental perception in formal education comprised students from primary levels (I and II, primary school) and high school (public and private). 


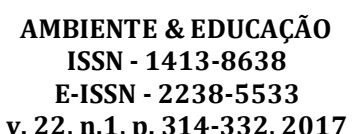

According to the Brazilian segmentation, the level I corresponds to the first five scholar years (students $c a$. 6 to 10 years old), while level II corresponds to the remaining four scholar years before the high-school (students $c a$. 11 to 14 years old). The questionnaires were applied inside the classroom by a teacher during August 2013 (the beginning of the second semester) and personal information was not required. The teacher did not have any relationship with the research and was instructed by the researcher to not induce any answer. The research was first approved by an ethical committee, and then authorized both by parents and schools of a town located in the southern Minas Gerais state, Brazil.

The data collection was based on previous experience in survey analysis and case studies applied in environmental perception (FREITAS, 2009; FREITAS et al., 2010) using questionnaires with structured and semi-structured questions, as well as images to collect perceptions and definitions about the environment. The definition of the sample was based on non-probabilistic sampling by judgment (BABBIE, 1999; REA, PARKER 2000), in which the researcher has the freedom to define the sample according to the research objectives (ALENCAR 2004). This approach is particularly appropriate for qualitative case studies, focused on specific targets (e.g. students of a given series) without excessive numerical (population) concern.

Three types of questionnaires were applied (one mixed and two semi-structured, with open and pseudo-open questions), and all of them included a blank space and students were asked to draw environments. The questionnaires differed from one another by the second question, as follows:

a) mixed (applied to 239 students). The categories in parenthesis were not revealed to students: indicate which one of the following actions you consider as a priority to achieve environmental conservation: - to ask forest police to protect the environment (sensibility); to contribute with money for people to conserve the environment (sensibility); to study about environment (comprehension); to visit ecological parks and zoos (comprehension); to separate garbage for recycling (responsibility); to avoid wasting water (responsibility); to avoid buying pollutant products (competence and citizenship); to preserve the life of animals and plants (competence and citizenship).

b) semi-structured/pseudo-open (applied to 81 students). The question was preceded by some examples of actions on behalf of the environment. The following are 
examples of actions to conserve the environment: - to separate garbage for recycling; to study and participate in courses about the environment; - to call upon neighbours to recover a polluted area; - to request for environmental control from police and the town hall. Choose only one of the actions that you consider as the most important to achieve the environmental conservation (it is not needed to cite any example above).

c) semi-structured/open (applied to 73 students). The question was: What is the main action for conserving the environment?

The following results were analysed:

a. Environmental perception: reductionist or complex, according to the drawing in the first question. Each drawing was scored according to the number of different elements composing the environment, i.e. elements from flora, fauna, other natural and artificial elements, the human being and its actions. This will be discussed later.

b. Actions on behalf of the environment: actions were classified according to sensibility, comprehension, responsibility, and competence and citizenship levels. Earlier studies (FREITAS et al., 2010; ABREU et al., 2008) have classified different actions as being comprised of the following categories: sensibility', 'comprehension', 'responsibility', and 'competence and citizenship'. The action indicated by each student was included into one of these categories after analysis and then compared with the results obtained by image analysis (environmental perception), using principal component analysis (PCA), which is a statistical procedure used to capture information from multivariate data (RENCHER, 2002). This analysis is capable of finding a correlation between environmental perception and the action types indicated by students, in order to capture typical actions of individuals with reductionist to complex conceptions about the environment; these data can support the introduction of practices in environmental education related to the concept of socio-ecological resilience into the scholar and social medium of a given population. The level of awareness related to the categories above is the same as reported elsewhere (FREITAS et al., 2010): sensibility refers to an alert process to something happening in the environment and it is considered the first step to achieve systemic thinking in environmental education; teaching and comprehension refers to the knowledge about the components and mechanisms ruling the natural system; responsibility recognizes the human being as the main agent in determining and guaranteeing the planet conservation; competence and citizenship is related to the capacity of evaluating and acting in the environmental 


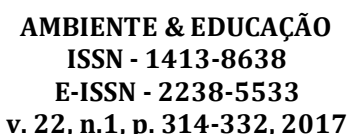

system, by conserving the socio-ecological system on behalf of a common benefit, under technical knowledge and altruist domain.

c. Data analysis: The data obtained from the environmental perception analysis and from the categories of actions on behalf of the environment was analysed using principal component analysis (PCA). The PCA is a statistical tool used to obtain information from multivariate data (such as actions and perceptions for a variety of students), whose variance is difficult to interpret by simple observation of a data matrix. The PCA consists of building $p$ latent variables (Y), also known as principal components, as linear combinations of the $p$ original variables $(\mathrm{X})$, in such a way that new orthogonal axes are built to explain the maximum variance possible using only a few dimensions:

$$
Y_{i}=\mathrm{e}_{i}^{T} \mathrm{X}=e_{i 1} X_{1}+e_{i 2} X_{2}+\ldots+e_{i p} X_{p}
$$

where the vector $e_{i}$ establishes the $i^{\text {th }}$ linear combination, for $i=1, \ldots, p$.

In practice, the data are tabulated in such a way that a matrix with $q$ rows (students) and $p$ columns (variables, that is, the four classes of actions on behalf of the environment obtained from Freitas et al. (2010) plus the environmental perception values) is built. The PCA yields a plot, whose axes correspond to $p$ principal components (PC), which explain the data variance in a successively decreasing way, that is, PC1 explains the largest data variance, followed by PC2, PC3 and so on. In general, two PCs are enough to describe significant data variance. Thus, a bidimensional plot is obtained and the coordinates of each variable in both axes are evaluated; the actions that yield the best estimations obtained by the analysis of environmental perception reflect the degree of complexity associated to each type of action. The multivariate analysis was performed using the Chemoface program (NUNES et al., 2012).

The drawing was chosen for the environmental perception analysis because it has been shown to be a universal language, inspired in previous studies devoted to use mental maps to collect perceptions (RIO, 1999). Asking students to represent elements composing the environment is a reliable way to capture conceptions about environment. In this work, the elements are classified as pertaining to 'fauna', 'flora', 'other natural elements', 'constructed elements' and 'human being and its actions'. One point was assigned to each class, except for the 'human being and its actions', to which two points were attributed, because the human being is the main intervener in the system and it is 
fundamental for the concept of socio-ecological resilience. Thus, a minimum of zero (0) and a maximum of six (6) points are achieved in each questionnaire (drawing).

The outcomes from these analyses supported the planning of activities in environmental education, which can be adapted to different educational segments.

\section{RESULTS AND DISCUSSION}

Three different questionnaires were given to 393 students lying on the basic level (119 Basic I and 131 Basic II) and high school (143), according to the Brazilian segmentation. The first part in all three questionnaires was the same and asked students to draw the environment, in order to capture their environmental perception and, consequently, to analyse their levels of complexity (see examples Figure 1). Most students understand environment as 'natural nature', i.e. as a place containing elements of flora, fauna and other natural elements, such as water, clouds, sun, soil, etc. In addition, the pictures reported an idealised, beautiful, harmonious, clear and untouched (preserved) nature; only a few students included the human being, his actions and built objects as part of the environment. Consequently, the environmental perceptions of these students were scored with $3.3 \pm 1.2,3.0 \pm 1.1$ and $3.2 \pm 1.2$ values in the mixed, pseudo-open and open questionnaires, respectively. There was no significant difference between the results obtained for the elementary level and high school students. These findings are different from those obtained in the literature about environmental perception using drawings, where children mostly included people, constructions, various plants and animals, mountains and especially elements such as sun and clouds in their drawings, in addition to including environmental problems (BARRAZA, 1999; GÜNINDI, 2012; ÖZSOY, 2012). Our data suggest that concepts of socio-ecological system and resilience must be reinforced in the educational strategies to improve the environmental complexity. 

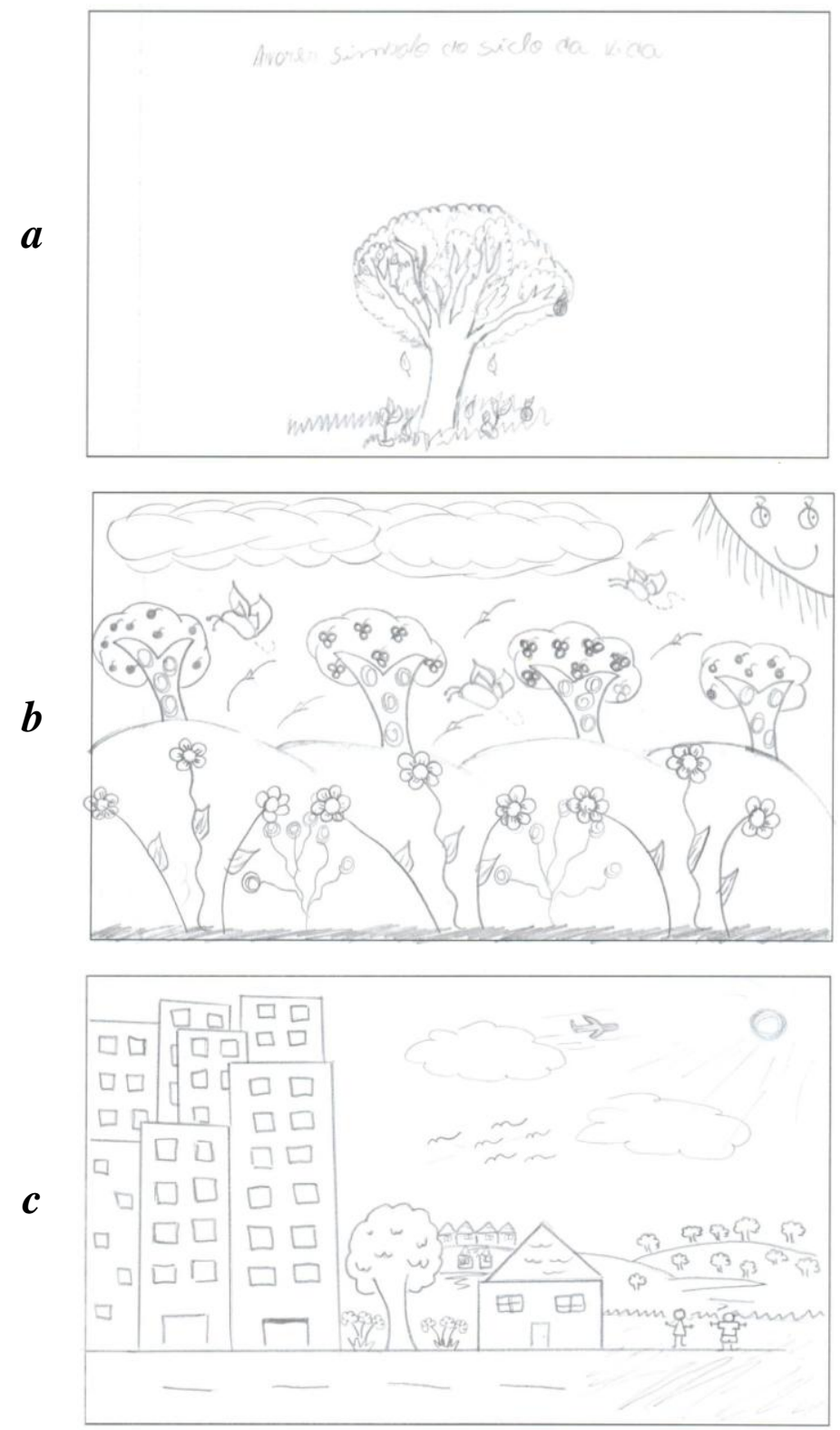

Figure 1. Examples of drawings with different scores in environmental perception: $\boldsymbol{a}=1$ point; $\boldsymbol{b}=3$ points; $\boldsymbol{c}=6$ points.

The actions on behalf of the environment considered as priorities by students were captured using three different ways, i.e. using three questionnaires for different students to:

1. Compare the annotated action with the environmental perceptions using principal component analysis (PCA);

2. Verify if there is any tendency in the response pattern using three different approaches: a) structured questions (one among eight alternatives was asked to be annotated, which is simpler to analyse, but with risk of induction); b) pseudo-open 
questions (include suggestions of actions, but the answerer does not need to annotate any of them); c) open questions (the answerer is free to write the action, which is more difficult to analyse, but there is no any risk of induction).

According to the responses for the structured questions in 239 questionnaires, competence and citizenship was the main action type indicated to achieve the environmental conservation (47\%), followed by responsibility (37\%), sensibility $(9 \%)$ and comprehension (7\%) action types. This result is surprising, because it is not consistent with the environmental perception analysis. The competence and citizenship category includes actions describing the answerer as a main contributor for high-impact conservation actions, while environmental perception scores of around 3 represent some deficiency in this field. This behaviour can indicate failure in the structured-based method, e.g. due to the language applied in the structured questions (technical terms like 'biodiversity' may attract/induce very young students).

To search for possible inaccuracy in the structured instrument for these students, the pseudo-open and open questionnaires were applied to 81 and 73 students, respectively. In both cases, most of actions declared by the students to achieve better environmental conservation were categorised into the responsibility class, while very few competence and citizenship actions were indicated (Table 1). These results confirm that the structured questions were inappropriate for these students, despite easier to analyse, and that pseudo-open and open questionnaires are more reliable. The use of examples of actions in the pseudo-open questionnaire for students with low environmental knowledge (e.g. the basic level I) can be favourable, because this is expected to spread the possibilities of annotation without induction, since only two respondents reproduced the action examples in their answers. In this sense, the structured question was found to be more limited, since it can induce annotations and also the alternative for this question may be chosen indiscriminately. Apparently, this limitation is attenuated for university students, according to studies performed elsewhere (Freitas et al. 2014), but pseudo-open and open questions are even then recommended. 


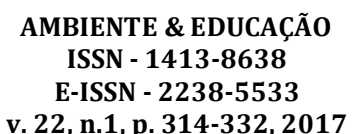

Table 1. Environmental actions considered as priority by the students of primary and high school students (\% of students) using structured, open and pseudo-open questionnaires.

\begin{tabular}{llll}
\hline Action type & Structured & Open & Pseudo-open \\
\hline Sensibility & 9 & 12 & 10 \\
Comprehension & 7 & 7 & 5 \\
Responsibility & 37 & 74 & 76 \\
Competence and citizenship & 47 & 7 & 9 \\
\hline
\end{tabular}

Overall, most of students indicated responsibility-type actions as the most important to achieve conservation, especially those related to the correct disposal of waste. Despite the recognition that human actions impact the environment, these actions are still specific (responsibility over the destination of solid wastes). The complexity and sustainability of actions, as well as the socio-ecological resilience, can be improved after exercises in environmental education. The challenge of the methodological proposal in environmental education of this work is to transform responsibility actions into competence and citizenship examples. Certainly, environmentally responsible actions practiced by students are welcomed, but the most important ones to be considered by these students are desirable to be moved towards more impacting proenvironmental actions.

\section{Principal Component Analysis (PCA)}

PCA generates two plots (scores and loadings plots) corresponding to samples (respondents) clustered according to their similarities (evaluated using variance analysis) and to the loadings that variables (the environmental perception and actions) have to separate each sample cluster in a given way. The first and second principal components (PC1 and PC2) are capable of clustering individuals according to the indicated actions and environmental perceptions in the questionnaires (the explained variances in PC1 and PC2, in \%, are given in Figure 2). The PCA obtained from the mixed questionnaire of primary plus high schools (76 from primary level I, 74 from primary level II and 89 from high school) showed that, in PC1, environmental perception correlated with sensibility and comprehension pro-environmental actions, while this correlation is negative in PC2, that is, small values of environmental perception were obtained by students who annotated sensibility and comprehension 
actions. Moreover, more complex perceptions correlated to responsibility and competence and citizenship actions in PC2, in agreement with the hypothesis of this work. However, this result is not reflected in the PCA for the primary level I, in which the contrary is observed, i.e. higher values in environmental perception were achieved by students who annotated sensibility and comprehension-type actions. These outcomes suggest a gain in environmental complexity with the level of instruction, and that there is not clarity about environmental issues in very young students, which is comprehensible. It is worth mentioning that comprehension and sensibility actions do not contribute significantly to cluster students from the primary level I and high school, respectively, due to the small amount of data corresponding to these actions (reflected by the vectors in the corresponding loadings plots). 

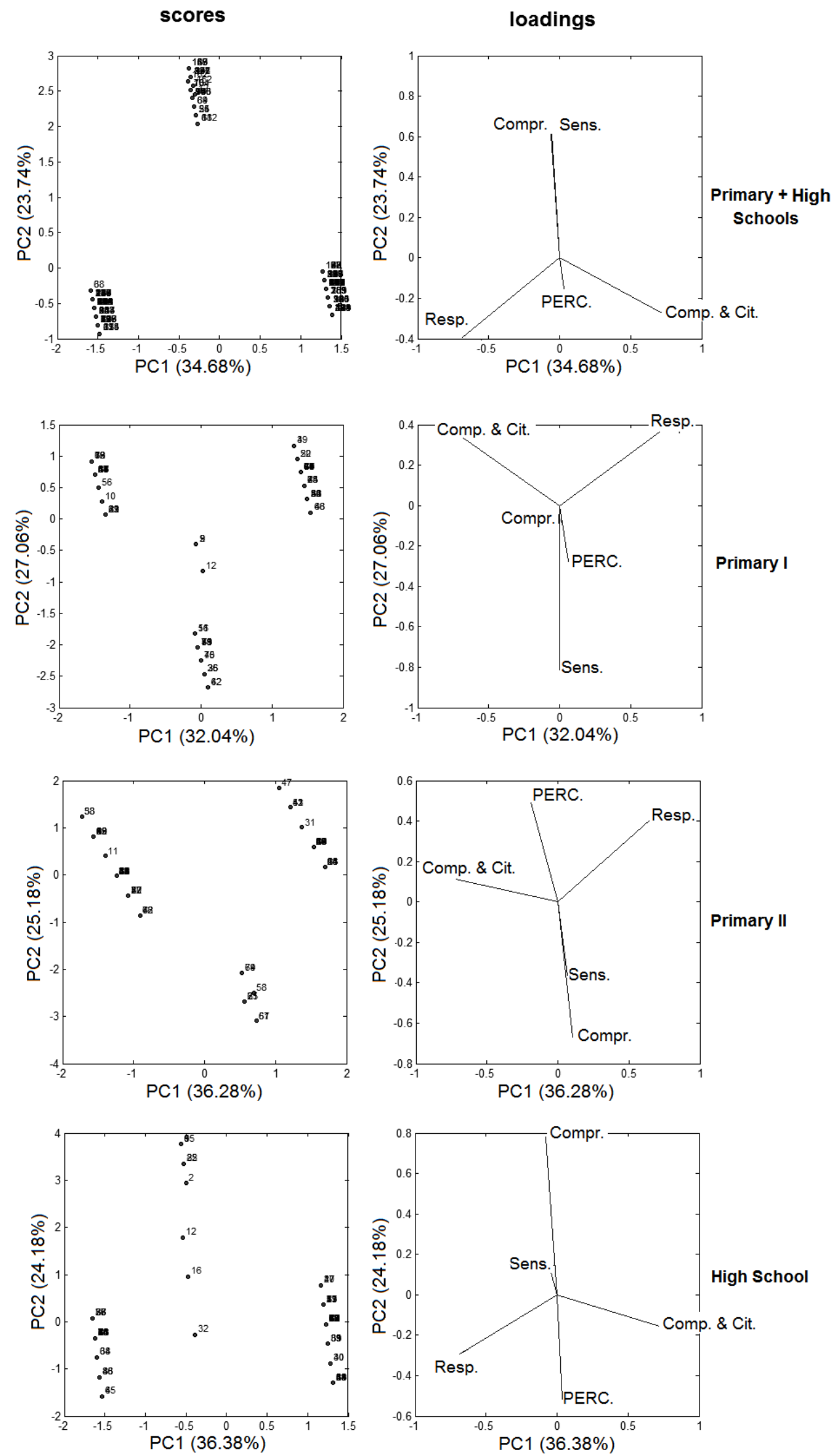

Figure 2. Scores and loadings plots obtained from the principal component analyses of the mixed questionnaire for the primary and high school students. 
Because the data corresponding to pro-environmental actions obtained from the structured questionnaire are not reliable for this class of students, the responses obtained from the pseudo-open and open questionnaires were used to develop pattern recognition analyses based on PCA, since they were considered less susceptible to induction and chance annotation (Figure 3). Both analyses indicate that students who obtained the highest values of environmental perception exhibit predilection to annotate competence and citizenship actions (see the congruency in the loadings of environmental perception and competence and citizenship in PC2). The open questionnaire is particularly interesting, because the corresponding loadings data in PC2 indicate the expected trend in the values of environmental perception as a function of pro-environmental actions. Thus, all three questionnaires gave similar tendencies, but the open questionnaire was more precise and, therefore, the hypothesis summarized in Figure 4 is confirmed.
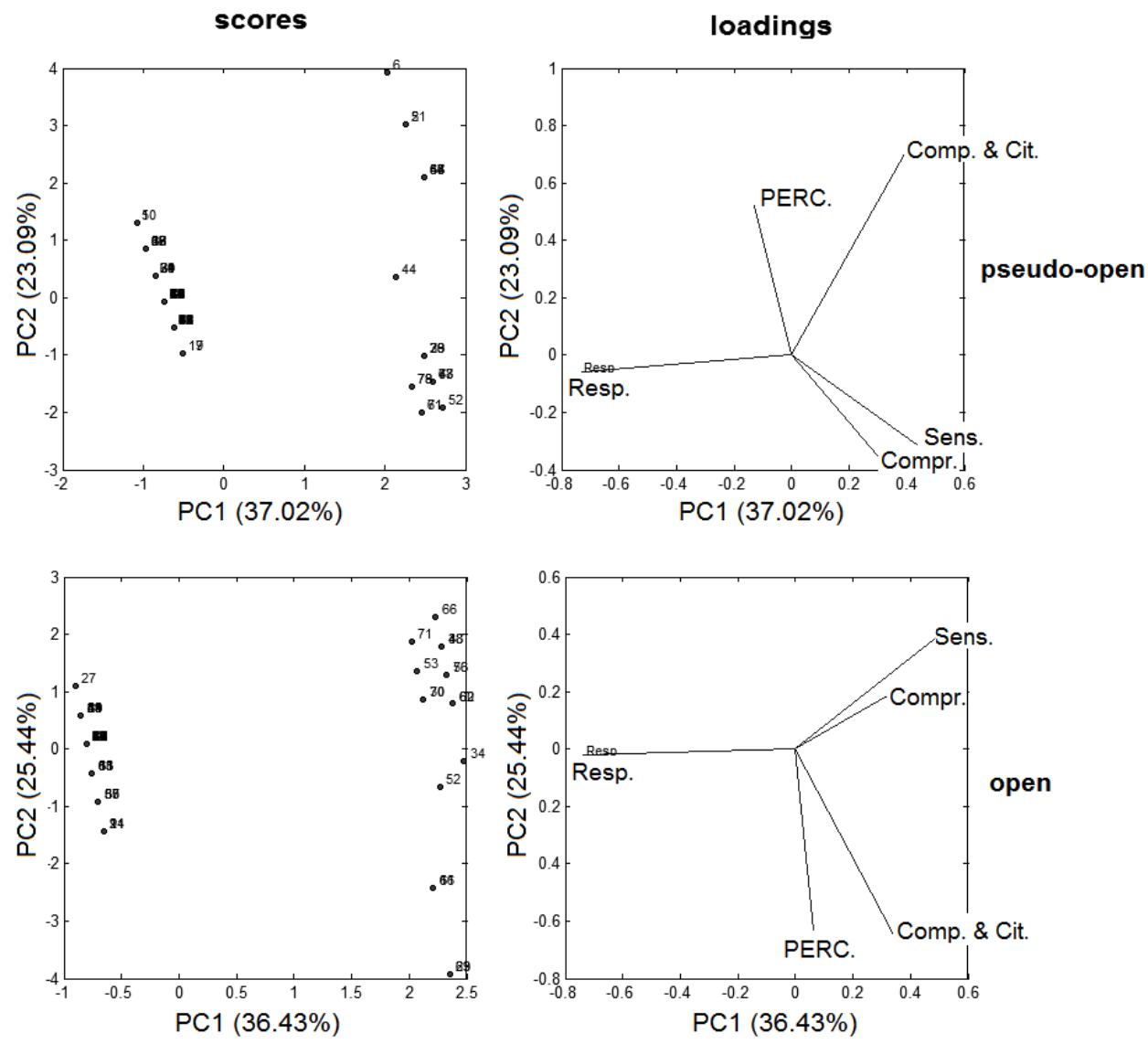

Figure 3. Scores and loadings plots obtained from the principal component analyses of the pseudo-open and open questionnaires. 


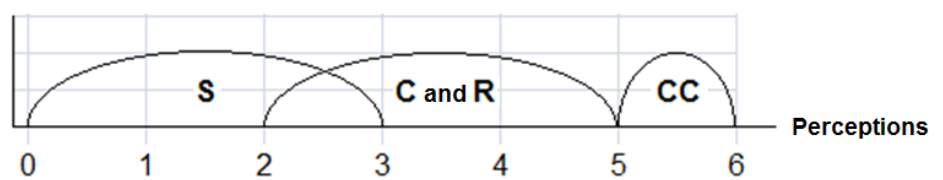

Figure 4. Relationship between the level of environmental perception and categories of actions on behalf of the environment. $\mathbf{S}=$ sensibility; $\mathbf{C}=$ comprehension; $\mathbf{R}=$ responsibility; $\mathbf{C C}=$ competence and citizenship.

The scheme in Figure 4 correlates the values obtained for environmental perception and the level of environmental action. According to the previous scale (FREITAS et al., 2014) and the purpose above, students indicating the environment only as fauna, flora and/or natural elements have around 3 points, thus revealing a reductionist conception of environment. This is consistent with sensibility-based actions, in which students consider the existence of environmental problems, but they do not recognize the environmental impact of their actions. In the other extreme, those attracting 5 or 6 points tend to include the human being and its actions as environmental components, consistent with actions in which the student's posture and interventions represent an example of environmental sustainability. The scale was proposed in accordance to the hypothesis that the level of environmental complexity (measured from the study of environmental perception) would be related to the actions, ranked according to the proposed categories. Since this hypothesis was confirmed by PCA analyses, improvement of the environmental conception (perception) should contribute for effective pro-environmental actions in the medium and long terms.

Analysis of the outcomes allowed the consolidation of a methodology to collect and analyse environmental perceptions and actions, which can test previous knowledge for use in activities of environmental education (Figure 5). The outcomes from this tool showed the student's deficiency in understanding how important it is for the human being to interact positively or negatively with the environment. Thus, a methodological proposal for teaching the environmental complexity, socio-ecological system and sustainability within the context of environmental education can be described with the aim of undoing incoherent (tending to reductionism rather than complex environmental conception) personal epistemological beliefs and to stimulate environmental conservation. For this task, it is worth mentioning that integration of existing knowledge and theory should advance understanding of socio-environmental systems (WEI et al., 
AMBIENTE \& EDUCAÇÃO

ISSN- 1413-8638

E-ISSN - 2238-5533

v. 22, n. 1, p. 314-332, 2017

2014). Despite a detailed, step-by-step description of teaching-learning activities is not possible to be given here at this moment, it would be helpful to follow some schemes to organize and synthesize the theory, as well as to develop the lectures (Figure 6).

\section{QUESTIONNAIRE OF ENVIRONMENTAL PERCEPTION}

1. Please draw in the space below what environment is to you . Add captions or annotations if you prefer.

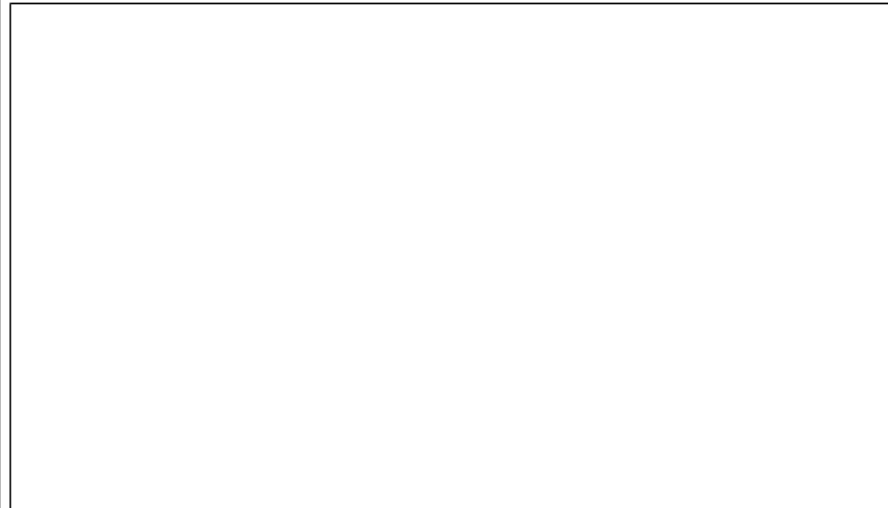

2. Please write a SINGLE action which, in your opinion, is the most important to achieve the environmental conservation

PROPOSAL FOR THE ANALYSIS OF THE QUESTIONNAIRE

Question 1: Punctuate the drawing from zero to six, using the following

Flora: 1 point; Fauna: 1 point; Other natural elements (water, clouds, sun, soil, etc.): 1 point; Constructed elements: 1 point, Human being and its actions: 2 points.

Question 2: Classify the actions into: sensibility, comprehension, responsibility and competence and citizenship

Figure 5. Proposed questionnaire for environmental perception and how to analyze it. 


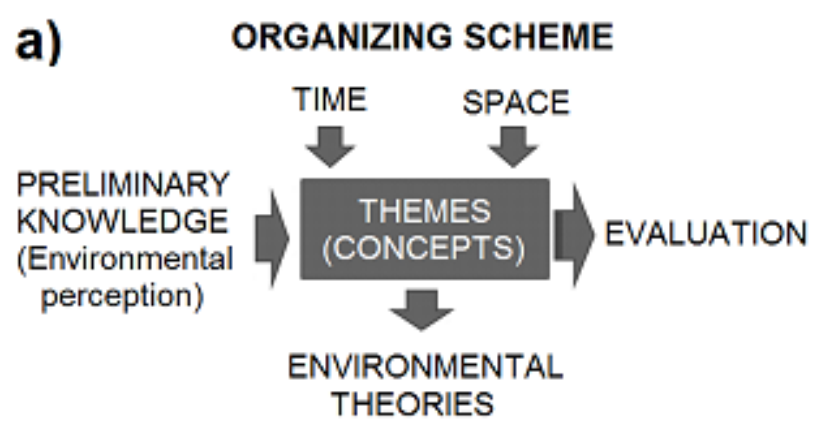

b)
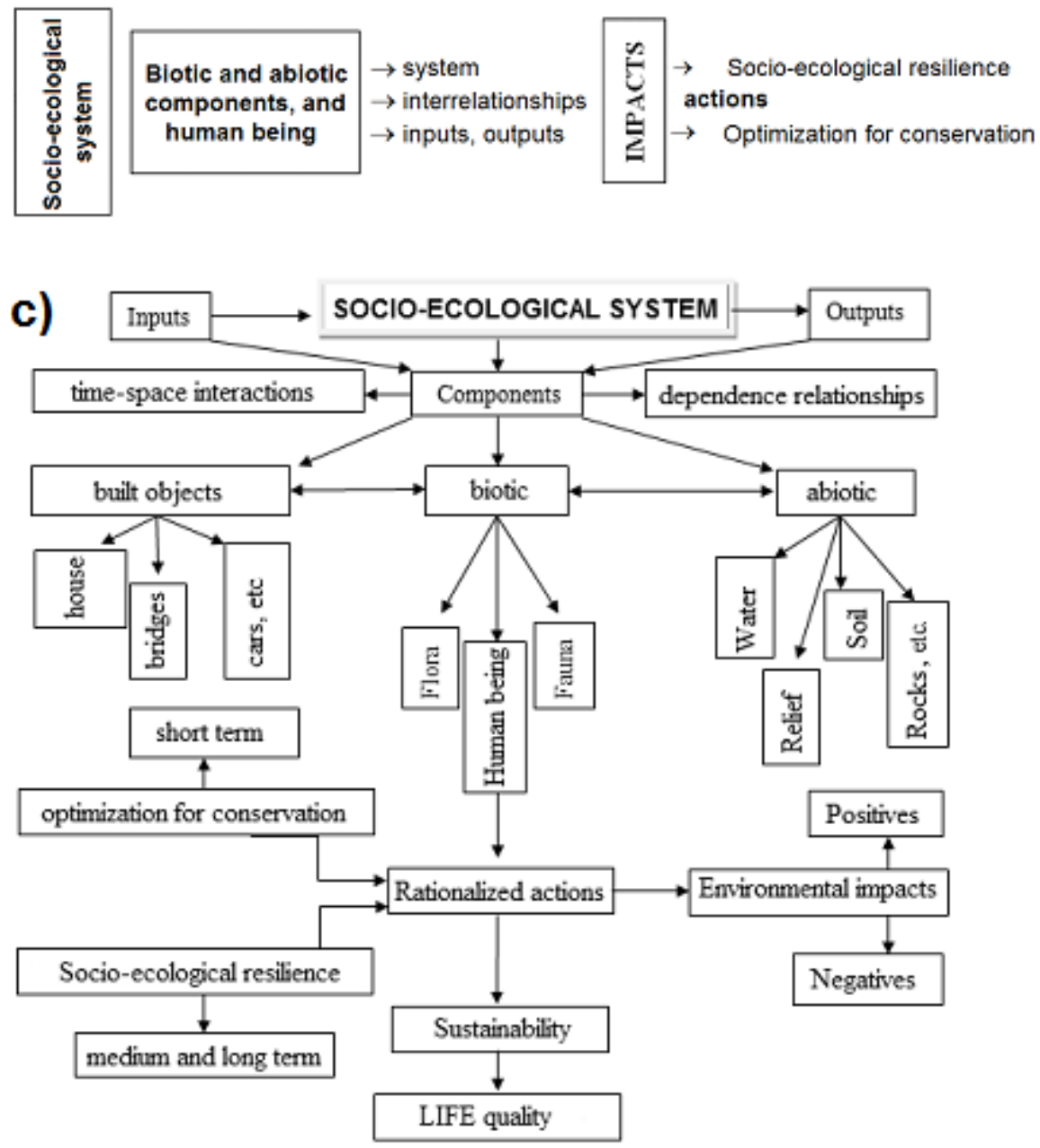

Figure 6. Proposed workflow aiming at: a) organizing the environmental reasoning; b) defining socio-ecological system; and c) building a conceptual map on socio-ecological system and proenvironmental actions to use in teaching-learning activities.

The overall discussion is in line with state-of-the art proposals in environmental education, which are supported by the education with resilience (DUBOIS, KRASNY, 2016) and the idea of shared values (IRVINE et al., 2016). According to this latter approach, individual values should be recognized, understood as part of the complexity 
of a system and then shared. When the environmental perception of a student is captured, the principles of resilience (e.g. calling back previous knowledge or using adaptive learning) and socio-ecological system (emphasizing the sharing of values) should take place by the educator, in order to improve the conception on environment and, ultimately, to provide tools for the practice of meaningful pro-environmental actions.

\section{CONCLUSIONS}

The hypothesis that students with reductionist conception about environment tend to develop flawed or insufficient actions, and that those with more complex concept tend to perform deeper and important actions, was confirmed. Thus, the proposed methodology is recommended in order to develop an environmental theory in a meaningful way, with the potential of changing mental conceptions and environmental actions. The methodology allows the educator utilising educational tools to promote the meaningful learning of concepts related to resilience and sustainability of the socioecological system, which are neither exogenous to the student nor unlinked to his/her reality. Efficient individual awareness, equipped with applicable theoretical background, can be built if anchored in previous knowledge and life history.

\section{REFERENCES}

ABREU, D. G.; CAMPOS, M. L. A. M.; AGUILAR, M. B. R. Educação ambiental nas escolas da região de Ribeirão Preto (SP): concepções orientadoras da prática docente e reflexões sobre a formação inicial de professores de química. Química Nova, São Paulo, v. 31, n. 3, p. 688-693, maio/jun. 2008.

ALENCAR, E. Metodologia científica e elaboração de monografia. Lavras: UFLA/FAEPE, 2004. $131 \mathrm{p}$.

AUSUBEL, D. P. The Psychology of Meaningful Verbal Learning. New York: Grune \& Stratton, 1963. 255 p.

BABBIE, E. Métodos de pesquisa de survey. Belo Horizonte: UFMG, 1999. 519 p.

BARRAZA. L. Childrens' drawings about the environment. Environmental Education Research, Abingdon, v. 5, n. 1, p. 49-66, 1999.

DUBOIS, B.; KRASNY, M. E. Educating with resilience in mind: Addressing climate change in post-Sandy New York City. Journal of Environmental Education, Abington, v. 47, n. 4, p. 255-270, 2016.

FAZEY, I. Resilience and higher order thinking. Ecology and Society, Wolfville, v. 15, n. 3, July 2010. 


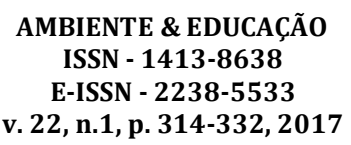

FISCHER, J. et al. Integrating resilience thinking and optimisation for conservation. Trends in Ecology \& Evolution, Amsterdam, v. 24, n. 10, p. 549-554, 2009.

FREITAS, M. R.; MACEDO, R. L. G.; FERREIRA, E. B. Percepção e complexidade ambiental: um somatório teórico para se atingir a conscientização ambiental. Educação Ambiental em Ação, Novo Hamburgo, v. 27, 2009.

FREITAS, M. R. et al. Em busca da conservação ambiental: a contribuição da percepção ambiental para a formação e atuação dos profissionais da química. Química Nova, São Paulo, v. 33, n. 4, p. 988-993, 2010.

FREITAS, M. R. et al. Environmental perception as a diagnostic probe of environmental complexity levels. Journal of Agricultural Education and Extension, London, v. 21, n. 2, p. 149-158, 2015.

FREITAS, M. R.; MACEDO, R. L. G.; FREITAS, M. P. Environmental perception as a tool to predict pro-environmental actions. Revista Brasileira de Educação Ambiental, São Paulo, v. 11, n. 1, p. 355-360, 2016.

GÜNINDI, Y. Environment in my point of view: analysis of the perceptions of environment of the children attending to kindergarten through the pictures they draw. Procedia - Social and Behavioral Sciences, Amsterdam, v. 55, n. 5, p. 594-603, 2012.

IRVINE, K. N.; O'BRIEN, L.; RAVENSCROFT, N.; COOPER, N.; EVERARD, M.; FAZEY, I.; REED, M. S.; KENTER, J. O. Ecosystem services and the idea of shared values. Ecosystem Services, Amsterdam, v. 21, p. 184-193, 2016.

KRASNY, M. E. A response to Scott's concerns about the relevance of environmental education research: applying social-ecological systems thinking and consilience to defining research goals. Environmental Education Research, Abingdon, v. 15, n. 2, p. 189-198, 2009.

KRASNY, M. E.; LUNDHOLM, C.; PLUMMER, R. Resilience in social-ecological systems: the roles of learning and education. Environmental Education Research, Abingdon, v. 16, n. 5/6, p. 463-474, 2010.

LABINTAH, S.; SHINOZAKI, M. Children drawing: Interpreting school-group student's learning and preferences in environmental education program at TanjungPiai National Park, Johor Malaysia. Procedia: Social and Behavioral Sciences, v. 116, p. 3765-3770, 2014.

LANDE, R.; ENGEN, S.; SAETHER, B. E. Optimal harvesting, economic discounting and extinction risk in fluctuating populations. Nature, London, v. 372, n. 6501, p. 88-90, Nov. 1994.

MARGULES, C. R.; PRESSEY, R. L. Systematic conservation planning. Nature, London, v. 405, n. 6783, p. 243-253, May 2000.

NUNES, C. A. et al. Chemoface: a novel free user-friendly interface for chemometrics. Journal of the Brazilian Chemical Society, São Paulo, v. 23, p. 2003-2010, Nov. 2012.

ÖZSOY, S. Investigating elementary school students' perceptions about environment through their drawings. Educational Sciences: Theory and Practice, Washington, v. 12, n. 2, p. 11321139, 2012.

REA, L. M.; PARKER, R. A. Metodologia de pesquisa: do planejamento à execução. São Paulo: Pioneira, 2000. 262 p.

RENCHER, A. C. Methods of Multivariate Analysis. New York: Wiley, 2002, 800 p. 
AMBIENTE \& EDUCAÇÃO

ISSN- 1413-8638

E-ISSN - 2238-5533

v. 22, n. 1, p. 314-332, 2017

RIO, V. del. Cidade da mente, cidade real: percepção ambiental e revitalização na área portuária do RJ. In: RIO, V. del; OLIVEIRA, L. (Org.). Percepção ambiental: a experiência brasileira. São Paulo: Nobel, 1999. p. 3-22.

ROUGHGARDEN, J.; SMITH, F. Why fisheries collapse and what to do about it. Proceedings of the Natural Academy of Sciences USA, Washington, v. 93, n. 10, p. 5078-5083, May 1996.

SHERREN, K.; FISCHER, J.; FAZEY, I. Managing the grazing landscape: insights for agricultural adaptation from a mid-drought photo-elicitation study in the Australian sheep-wheat belt. Agricultural Systems, Essex, v. 106, n. 1, p. 72-83, Feb. 2012.

WEI, C. A.; BURNSIDE, W. R.; CHE-CASTALDO, J. P. Teaching socioenvironmental synthesis with the case studies approach. Journal of Environmental Studies and Sciences, Cham, v. 5, n. 1, p. 42-49, 2015.

WOOLFOLK, A. E.; WINNE, P. H.; PERRY, N. E.; SHAPKA, J. Educational Psychology (4th ed). Toronto: Pearson Canada, 2010. 